\title{
PENGAWASAN MASYARAKAT DALAM MENJAGA KELESTARIAN EKOSISTEM SUNGAI RASAU DI DESA PETAK BAHANDANG KECAMATAN TASIK PAYAWAN KABUPATEN KATINGAN
}

\author{
Community Monitoring in Maintaining the Conservation of Sungai Rasau Ecosystem in Petak Bahandang \\ Village, Tasik Payawan District, Katingan District
}

\section{Nurhasanah* \\ Ariyanto}

Universitas Muhammadiyah

Palangkaraya, Palangka Raya,

Central Kalimantan, Indonesia

email:

nurhasanah@umpalangkaraya.ac.id

\begin{abstract}
Abstrak
Sungai merupakan salah satu bagian yang tidak dapat dilepaskan dari kehidupan kita sehari - hari. Sungai yang ada di Kabupaten Katingan dimanfaatkan masyarakat untuk berbagai kegiatan, antara lain transportasi, MCK (mandi, cuci, kakus/WC), dan kegiatan ekonomi mereka sehari-harinya. Namun kenyataan dilapangan menunjukan bahwa kualitas air di sungai rasau sudah tidak layak di gunakan oleh masyarakat air yang keruh pekat membuat mereka harus berfikir dua kali untuk menggunakannya. Tujuan penelitian ini adalah untuk menjelaskan dan mendeskripsikan Pengawasan Masyarakat Dalam Menjaga Kelestarian Ekosistem Sungai Rasau Di Desa Petak Bahandang Kecamatan Tasik Payawan Kabupaten Katingan Provinsi Kalimantan Tengah. Penelitian ini menggunakan metode penelitian kualitatif, yaitu bermaksud mengembangkan konsep, menghimpun fakta yang didukung dan ditunjang oleh data yang riil. Sumber data dalam penelitian ini adalah pegawai Desa Petak Bahandang, masyarakat Desa Petak Bahandang, serta dokumen yang berkaitan dengan Pengawasan Masyarakat Dalam Menjaga Kelestarian Ekosistem Sungai Rasau Di Desa Petak Bahandang Kecamatan Tasik Payawan Kabupaten Katingan Provinsi Kalimantan Tengah.Teknik pengumpulan data adalah dengan observasi, dokumentasi dan wawancara mendalam. Dari hasil penelitian bahwa Pengawasan Masyarakat Dalam Menjaga Kelestarian Ekosistem Sungai Rasau Di Desa Petak Bahandang Kecamatan Tasik Payawan Kabupaten Katingan Provinsi Kalimantan Tengah masih rendah karena beberapa faktor, pekerjaan, pendidikan dan leadership. Terutama dalam perencanaan, pengawasan dan pemeliharaan, masyarakat masih kurang berperan serta didalamnya.
\end{abstract}

Kata Kunci:

Pengawasan

Kelestarian Lingkungan

Ekosistem

Sungai

Keywords:

Supervision

Environmental Sustainability

Ecosystem

River

\section{Accepted}

January 2017

\section{Published}

April 2017

\begin{abstract}
The river is one part that cannot be separated from our daily lives. The river in Katingan Regency is used by the community for various activities, including transportation, MCK (bathing, washing, toilet), and their daily economic activities. However, the reality in the field shows that the water quality in the Rasau River is not suitable for use by the people, the turbid water makes them have to think twice to use it. The purpose of this study was to explain and describe Community Supervision in Maintaining the Conservation of Sungai Rasau Ecosystem in Petak Bahandang Village, Tasik Payawan District, Katingan District, Central Kalimantan Province. This research uses qualitative research methods, which are intended to develop concepts, gather facts that are supported and supported by real data. Sources of data in this study are the employees of the Petak Bahandang Village, the Petak Bahandang Village community, and documents relating to Community Monitoring in Maintaining the Conservation of Sungai Rasau Ecosystem in Petak Bahandang Village, Tasik Payawan District, Katingan District, Central Kalimantan. Data collection techniques are observation, documentation and in-depth interviews. From the results of the study that Community Monitoring in Maintaining the Conservation of Sungai Rasau Ecosystem in Petak Bahandang Village, Tasik Payawan Subdistrict, Katingan District, Central Kalimantan Province is still low due to several factors, work, education, and leadership. Especially in planning, supervision, and maintenance, the community still lacks participation in it.
\end{abstract}

\section{PENDAHULUAN}

Usaha pemberdayaan masyarakat, dalam arti pengelolaan pembangunan desa harus dibangun dengan berorientasi pada potensi viskal, perlibatan masyarakat serta adanya usaha yang mengarah pada kemandirian masyarakat desa. Keikut sertaan masyarakat dalam pelaksanaan pembangunan secara aktif baik pada 
pembuatan rencana pelaksanaan maupun penilaian pembangunan menjadi demikian penting sebagai tolak ukur kemampuan masyarakat untuk berinisiatif dan menikmati hasil pembangunan yang telah dilakukan. Dalam meningkatkan dan mendorong munculnya sikap partisipasi, maka yang perlu dipahami oleh pengembang masyarakat adalah kebutuhan -kebutuhan nyata yang dirasakan oleh individu maupun masyarakat. Kabupaten Katingan merupakan salah satu daerah yang mempunyai sungai besar. Sungai yang ada di Kabupaten Katingan dimanfaatkan masyarakat untuk berbagai kegiatan, antara lain transportasi, MCK (mandi, cuci, kakus/WC), dan kegiatan ekonomi mereka sehari-harinya. Sumberdaya alam yang melimpah di desa petak bahandang ini harusnya berirama baik dengan kesejahteraan masyarakat petak bahandang. Akan tetapi pada kenyataannya banyak permasalahan yang menyelimuti masyarakat di desa petak bahandang diantaranya kemiskinan, pendidikan, kesehatan, fasilitas umum yang tidak memadai dan permasalahan kondisi air yang kualitasnya hampir tidak layak konsumsi. Dengan kurang efektifnya peran masyarakat dalam pengawasan terhadap program tidak buant sampah disungai membuat masyarakat kurang memanfaatkan hasil dari beberapa pembangunan dengan seutuhnya. Minimnya kesadaran akan pembangunan menjadikan keterlibatan dalam berpartisipasi masyarakat di desa petak bahandang rendah.

Sungai merupakan salah satu sumber air yang dapat dimanfaatkan untuk berbagai keperluan dan kebutuhan hidup sehari-hari sudah selayaknya dilakukan berbagai upaya untuk menjaga kelestarian dankealamiannya. Sungai yang melewati sebagaian desa yang ada dikabupaten katingan kondisinya sangat memperihatinkan. Air sungai Katingan sekarang benarbenar sangat keruh dari biasanya, sehingga warga yang bermukiman dibantaran sungai mengeloh dengan kondisi air tersebut. Sekarang keseharian masyarakat yang biasanya mengandalkan air sungai untuk mencuci, mandi dan yang lain sebagainya, kini masyarakat harus berfikir dua kali untuk menggunakan air yang sangat keruh tersebut. Masyarakat setempat mengatakan air sungai yang semulanya layak digunakan oleh masyarakat kini sudah berubah menjadi tidak layak lagi untuk digunakan. Dengan memburuknya kualitas air yang ada disungai katingan ini mereka takutnya berimbah akan menjadi penyakit untuk mereka, ada juga masyarakat yang berusaha melakukan penambangan pada daerah aliran sungai sebagai mata pencarian untuk mendapat sesuap nasi. Karena memang sumber usaha lainya belum ada, ini pun berkaitan dengan anjloknya harga dari beberapa komuditas hasil perkebunan seperti karet dan rotan.

Dengan kualitas air yang turun masyarakat juga takut ekosistem yang adadisungai jadi berkurang, sementara masyarakat sekitar sebagian adalah nelayan. Yang mana mereka menggantungkan ekonomi mereka disungai. Oleh sebab itu mereka sangat memerlukan perhatian pemerintah terkait untuk menangani masalah tersebut. Agar masalah air tidak semakin hari semakin parah, permasalahan yang dilapangan masih ada masyarakat mebuang sampah disungan, dan pertambangan yang dilakukan masyarakat agar mereka bisa di pekerjaan yang layak agar tidak merusak ekosistem itu sendiri.

Pengawasan merupakan salah satu fungsi manajemen. Fungsi ini sangat penting dan sangat menentukan pelaksanaan proses manajemen, karena harus dilakukan sebaik dengan sebaik-baiknya. Menurut Brantas (2009:188) pengawasan ialah proses pemantauan, penilaian, dan pelaporan rencana atas pencapaian tujuan yang telah ditetapkan untuk tindakan koreksi guna penyempurnaan lebih lanjut. Pengawas hanya sebatas memberi saran. Pengawasan berkaitan erat dengan fungsi perencanaan dan kedua fungsi ini merupakan hal yang saling mengisi karena:

I. Pengawasan harus terlebih dahulu direncanakan.

2. Pengawasan baru dapat dilakukan jika ada rencana. 
3. Pelaksanaan rencana akan baik, jika pengwasan dilakukan dengan baik.

4. Tujuan baru dapat diketahui tercapai dengan baik atau tidak setelah pengawasan atau penilaian dilakukan

Menurut Slamet (Suryono,200I:124) partisipasi masyarakat dalam pembangunan diartikan sebagai ikut sertanya masyarakat dalam pembangunan, ikut dalam kegiatan pembangunan dan ikut serta memanfaatkan dan ikut menikmati hasil-hasil pembangunan. Konsep partisipasi masyarakat dalam pembangunan sudah mulai dikenalkan oleh pemerintah sejak awal tahun 1980an melalui istilah pemberdayaan masyarakat. Menurut Cohen dan Uphoff tentang partisipasi masyarakat dalam pembangunan terlibat dalam 4 (empat) indikator yakni, perencanaan, pelaksanaan, pengawasan, pemanfaatan dan pemeliharaan

Ekosistem terbentuk oleh komponen hidup dan tak hidup di suatu tempat yang berinteraksi membentuk suatu kesatuan yang teratur. Keteraturan itu terjadi oleh adanya asrus materi dan energi yang terkendalikan oleh arus informasi antara komponen dalam ekosistem itu. Masing-masing komponen itu mempunyai fungsi atau relung. Selama masing-masing komponen itu melakukan fungsinya dan bekerja sama dengan baik, keteraturan ekosistem itu pun terjaga. Keteraturan ekosistem menunjukkan, ekosistem tersebut ada dalam suatu keseimbangan tertentu. Keseimbangan itu tidaklah bersifat statis, melainkan dinamis. Artinya, ia selalu berubah-ubah dan perubahan itu bisa terjadi secara alamiah ataupun karena perbuatan manusia.

\section{METODOLOGI}

Alasan peneliti menggunakan penelittian metode kualitatif, karena tujuannnya adalah untuk mendiskrifsikan atau mengambarkan apa adanya mengenai suatu variable, gejala, keadaan atau fenomena sosial tertentu. Dalam hal ini guna menganalisis data yang diperoleh secara mendalam dan menyeluruh, dan perlu menyajikan suatu pandangan yang mendetail tentang topik tersebut. Manfaat menggunakan metode deskriptif Kualitatif dalam penelitian ini adalah untuk mengetahui Bagaimana Pengawasan Masyarakat Dalam Menjaga Kelestarian Ekosistem Sungai Rasau Di Desa Petak Bahandang Kecamatan Tasik Payawan Kabupaten Katingan Provinsi Kalimantan Tengah. Peneliti langsung turun kelapangan dan berusaha mengumpulkan datasecara lengkap dengan pokok permasalahan yang berhubungan dengan Pengawasan Masyarakat Dalam Menjaga Kelestarian Ekosistem Sungai Rasau Di Desa Petak Bahandang Kecamatan Tasik Payawan Kabupaten Katingan Provinsi Kalimantan Tengah.

\section{HASIL DAN PEMBAHASAN}

Pengawasan Masyarakat Dalam Menjaga Kelestarian Ekosistem Sungai Rasau Di Desa Petak Bahandang Kecamatan Tasik Payawan Kabupaten Katingan Provinsi Kalimantan Tengah masih rendah. Berdasarkan teori Cohen dan Uphoff tentang partisipasi masyarakat dalam pembangunan terlibat dalam 4 (empat) indikator yakni, perencanaan, pelaksanaan, pengawasan, pemanfaatan dan pemeliharaan. Dari 4 (empat) indikator tersebut, ada I indikator yang masih menunjukkan partisipasi masyarakat dalam program tidak buang sampah disungai masih rendah.

Indikator yang dimaksud adalah Partisipasi masyarakat dalam pengawasan kegiatan program tidak buang sampah disungai, masih kurang baik. Pengawasan hanya dilakukan oleh pemerintah saja, masyarakat yang kurang mengawasi kegiatan, disebabkan karena memang masih minimnya kesadaran masyarakat dalam hal pengawasan, yang masyarakat tahu hanyalah pihakpihak yang terkait sebagai pelaksana program yang bertanggung jawab untuk mengawasi program tidak buang sampah disungai. Pemerintah sudah berusaha melibatkan masyarakatnya agar mau berpartisipasi 
dalam mengawasi program yang direncanakan sebelumnya.

I. Perencanaan

partisipasi masyarakat dalam hal perencanaan Program Tidak Buang Sampah diSungai Desa Petak Bahandang Kecamatan Tasik Payawan kurang baik. Memang masyarakat selalu dilibatkan dalam perencannan Program Tidak Buang Sampah Disungai pada tahapan perencanaan. Akan tetapi ada beberapa kendala, terutama waktu. Dikarenakan masyarakat Petak Bahandang yang kesehariannya disibukkan dengan aktivitasnya yaitu ada yang bekerja, berladang dan yang lainnya.

2. Pelaksanaan

Terkait pelaksanaan Program Tidak Buang Sampah diSungai Rasau diatas. Menunjukkan bahwa adanya partisipasi masyarakat dalam pelaksanaan Program tersebut yang dilakukan, terutama masyarakat yang ada di desa Petak Bahandang Kaktifan Masyarakat ditujukan dalam bentuk ikut melaksanakan program Tidak Buang samapah disungai. Dengan cara membantu melalui tenaga dan materi. Secara keseluruhan pelaksanaan program yang dilakukan Masyarakat berjalan dengan baik. Meskipun ada beberapa hambatan dalam pelaksanaannya program tidak buang sampah disungai, seperti kendala kurangnya tempat sampah yang disediakan oleh pemerintah.

3. Pengawasan

Berdasarkan hasil yang dilakukan oleh peneliti, dapat disimpulkan bahwa pengawasaan akan jalannya program tidak buang sampah disungai masih kurang. Dimana controlling hanya dilakukan oleh pihak pemerintah yang memang bertanggung jawab dalam pengawasan program yang direncanakan sebelumnya. Namun, pengawasan yang dilakukan oleh masyarakat desa Petak Bahandang masih belum terlihat maksimal.
4. Pemanfaatan dan pemeliharaan

Berdasarkan hasil wawancara yang dilakukan oleh peneliti terkait pasrtisipasi masyarakat dalam hal pemanfaatan dan pemeliharaan. Bisa disimpulkan bahwa, masih kurangnya kepedulian masyarakat petak bahandang dalam memelihara dan menjaga hasil pembangunan. Pada pemanfaatan, masyarakat sudah dapat memanfaatkan sebaik-baiknya akan tetapi tidak diiringi sikap dalam hal perawatan atau pemeliharaan. Adanya sikap peduli terhadap hasil pembangunan hanya dalam pemanfaatan tetapi kurang sampai dalam perawatan atau pemeliharaan dan juga pengembangan.

\section{KESIMPULAN}

Berdasarkan hasil penelitian dan temuan-temuan di lapangan, maka penyimpulan akhir tentang Pengawasan Masyarakat Dalam Menjaga Kelestarian Ekosistem Sungai Rasau Di Desa Petak Bahandang Kecamatan Tasik Payawan Kabupaten Katingan Provinsi Kalimantan Tengah masih rendah. Berdasarkan teori Cohen dan Uphoff tentang partisipasi masyarakat dalam pembangunan terlibat dalam 4 (empat) indikator yakni, perencanaan, pelaksanaan, pengawasan, pemanfaatan dan pemeliharaan. Dari 4 (empat) indikator tersebut, ada $\mathrm{I}$ indikator yang masih menunjukkan partisipasi masyarakat dalam program tidak buang sampah disungai masih rendah. Sehingga diperlukan Leadership dari kepala desa petak bahandang harus bisa membangkitkan semangat keaktifan masyarakatnya dalam proses pembangunan dengan mengkoordinasikan serta mengoptimalkan kelembagaan desa, seperti Lembaga Pemberdayaan Desa (LPM), Karang Taruna dan lain sebagainya. Serta Megoptimalkan kelembagaan terkait pada desa petak bahandang ini, guna pemanfaatannya bisa dikembangkan lagi agar masyarakat secara menyeluruh dapat merasakan maanfaat dari program tersebut. 


\section{REFERENSI}

Brantas. 2009. Dasar - Dasar Manajemen. Bandung : Penerbit alfabeta.

Conyers, Diana. 200I. Perencanaan Sosial di Dunia ketiga. Yogyakarta: UGM Press.

Emzir. 201I. Metodologi Penelitian Kualitatif Analisis Data. Jakarta. Rajawali Pers

Fasli Djalal \& Dedi Supriadi. 200I. Reformasi Pendidikan dalam Konteks Otonomi Daerah. Yogyakarta: AdicitaKarya Nusa.

Mahmudi. 20I0. Manajemen Kinerja Sektor Publik, Edisi. kedua. Sekolah Tinggi Ilmu Manajemen YKPN. Yogyakarta.

M,Nasir. 2003. Metode Penelitian. Jakarta: Galia Indonesia.

Nasution M.N. 2004. Manajemen Jasa Terpad. Bogor:Ghalia Indonesia.

Pasolong, Harbani. 20II. Teori Administrasi Publik. Bandung: Alfabeta.

Ratminto \& Atik Septi Winarsih. 2007. Manajemen Pelayanan. Yogyakarta: Pustaka Pelajar

Sumaryadi. I Nyoman. 20I0. Efektifitas Implementasi Otonomi Daerah. Jakarta: Citra Utama.

Tilaar, H.A.R. 2009. Kekuasaan dan Pendidikan: Manajemen Pendidikan Nasional Dalam PusaranKekuasaan. Jakarta: Rineka Cipta. 